Jellyfish Blooms: Causes, Consequences, and Recent Advances 
Developments in Hydrobiology 206

Series editor

K. Martens 


\section{Jellyfish Blooms: Causes, Consequences, and Recent Advances}

Proceedings of the Second International Jellyfish Blooms Symposium, held at the Gold Coast, Queensland, Australia, 24-27 June, 2007

\section{Editors}

Kylie A. Pitt ${ }^{1}$ \& Jennifer E. Purcell ${ }^{2}$

\footnotetext{
${ }^{1}$ Australian Rivers Institute and Griffith School of Environment, Griffith University, Australia

${ }^{2}$ Western Washington University, Shannon Point Marine Center, Washington, USA
}

Reprinted from Hydrobiologia, Volume 616 (2009)

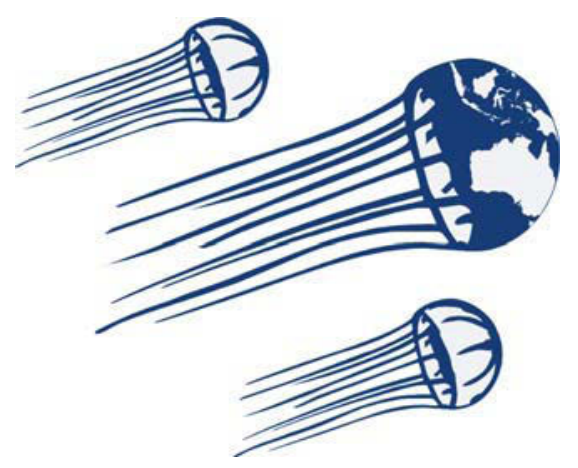

\section{(U) Griffith UNIVERSITY}

AUSTRULAN RIVERS INSTITUTE

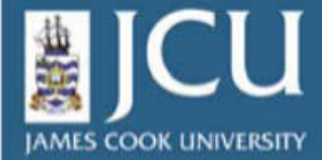

IAMES COOK UNIVERSITY
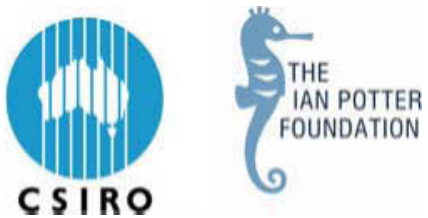

\section{㩏 Springer}




\section{Library of Congress Cataloging-in-Publication Data}

A C.I.P. Catalogue record for this book is available from the Library of Congress.

ISBN: 978-1-4020-9748-5

Published by Springer,

P.O. Box 17, 3300 AA Dordrecht, The Netherlands

Cite this publication as Hydrobiologia vol. 616 (2009).

Cover illustration: An aggregation of the giant jellyfish, Nemopilema nomurai, in a set net in Kyoto Prefecture, Japan. Photo by Yomiuri Shinbun.

\section{Printed on acid-free paper}

\section{All Rights reserved}

(C) 2008 Springer Science+Business Media B.V.

No part of this material protected by this copyright notice may be reproduced or utilized in any form or by any means, electronic or mechanical, including photocopying, recording or by any information storage and retrieval system, without written permission from the copyright owner. 


\section{TABLE OF CONTENTS}

Preface

K.A. Pitt, J.E. Purcell

Obituary: Francesc Pagès (1962-2007)

J.-M. Gili, J.L. Acuña, H.E. González

\section{LARGE SCALE APPROACHES}

The growth of jellyfishes

M.L.D. Palomares, D. Pauly

Extension of methods for jellyfish and ctenophore trophic ecology to large-scale research

J.E. Purcell

Patterns of jellyfish abundance in the North Atlantic

M.J. Gibbons, A.J. Richardson

Jellyfish in ecosystems, online databases, and ecosystem models

D. Pauly, W. Graham, S. Libralato, L. Morissette, M.L. Deng Palomares

Quantifying movement of the tropical Australian cubozoan Chironex fleckeri using acoustic telemetry

M.R. Gordon, J.E. Seymour

Acoustic survey of a jellyfish-dominated ecosystem (Mljet Island, Croatia)

G. Alvarez Colombo, A. Benović, A. Malej, D. Lučić, T. Makovec, V. Onofri, M. Acha,

A. Madirolas, H. Mianzan

Stock enhancement of the edible jellyfish (Rhopilema esculentum Kishinouye) in Liaodong Bay, China: a review

J. Dong, L.-x. Jiang, K.-f. Tan, H.-y. Liu, J.E. Purcell, P.-j. Li, C.-c. Ye

\section{TROPHIC ECOLOGY AND NUTRIENT DYNAMICS}

Stable isotope and fatty acid tracers in energy and nutrient studies of jellyfish: a review

K.A. Pitt, R.M. Connolly, T. Meziane

$119-132$

Influence of jellyfish blooms on carbon, nitrogen and phosphorus cycling and plankton production

K.A. Pitt, D.T. Welsh, R.H. Condon

Influence of decomposing jellyfish on the sediment oxygen demand and nutrient dynamics

E.J. West, D.T. Welsh, K.A. Pitt 


\section{EVOLUTION AND MOLECULAR APPROACHES}

A review and synthesis on the systematics and evolution of jellyfish blooms: advantageous aggregations and adaptive assemblages

W.M. Hamner, M.N Dawson

A character-based analysis of the evolution of jellyfish blooms: adaptation and exaptation

M.N Dawson, W.M. Hamner

A new Taqman ${ }^{\odot}$ PCR-based method for the detection and identification of scyphozoan jellyfish polyps

K.M. Bayha, W.M. Graham

Comparative analysis of nuclear ribosomal DNA from the moon jelly Aurelia sp.1 (Cnidaria: Scyphozoa) with characterizations of the 18S, 28 S genes, and the intergenic spacer (IGS)

J.-S. Ki, I.-C. Kim, J.-S. Lee

\section{BENTHIC STAGES OF THE LIFE HISTORY}

The potential importance of podocysts to the formation of scyphozoan blooms: a review

M.N. Arai

Effects of temperature and light intensity on asexual reproduction of the scyphozoan, Aurelia aurita (L.) in Taiwan

W.-C. Liu, W.-T. Lo, J.E. Purcell, H.-H. Chang

Substrate preferences of scyphozoan Aurelia labiata polyps among common dock-building materials

R.A. Hoover, J.E. Purcell

\section{GENERAL BIOLOGY AND ECOLOGY}

Ontogenetic changes in the ecological function of the association behavior between jack mackerel Trachurus japonicus and jellyfish

R. Masuda

Kinematic properties of the jellyfish Aurelia sp.

T. Bajcar, V. Malačič, A. Malej, B. Širok 


\section{JELLYFISH BLOOMS}

\section{Preface}

Published online: 30 September 2008

(c) Springer Science+Business Media B.V. 2008

Jellyfish are among the most conspicuous animals in the ocean. They are fascinating ecologically as they are major consumers of zooplankton, are widely distributed, and most have complex life histories and demographics. They also have societal and economic significance as they clog cooling water intakes of coastal industries and ships, interfere with fisheries and deter holidaymakers from enjoying a swim at the beach. Although it is not a ubiquitous phenomenon, there is little doubt that some species of jellyfish are flourishing in parts of the world. The causes of jellyfish blooms are equivocal, but have been related to overfishing, climate change, eutrophication, and the increasing amount of artificial marine structures that provide suitable habitat for the benthic stage of the life history.

The Second International Jellyfish Blooms Symposium was held on the Gold Coast, Queensland, Australia, in June 2007 and followed the highly successful inaugural symposium that was held in Alabama, USA in 2000. In the intervening years, some remarkable changes have occurred. Most notable has been the population explosion of the 'giant jellyfish' (>1-m diameter), Nemopilema nomurai, in East Asian waters. The ctenophore, Mnemiopsis leidyi, infamous for its invasion of the Black Sea,

Guest editors: K. A. Pitt \& J. E. Purcell

Jellyfish Blooms: Causes, Consequences, and Recent Advances has also recently appeared in northern European waters. Techniques for studying jellyfish have also advanced. In particular, molecular techniques are showing an increasing diversity of cryptic species of jellyfish and are being developed as tools to screen the hulls of ships and other infrastructure for invasive polyps. Acoustic techniques are being refined and are increasingly being used to quantify abundances, distributions, and movements of medusae. Natural tracers, such as stable isotopes and fatty acids more frequently are being used to complement traditional gut content analyses to examine trophic relationships. The polyp stage of the life history also recently has gained greater recognition because of its potential contribution to the development of blooms.

Thus, the 61 delegates from 17 nations who gathered in Australia had much to discuss! Professor Daniel Pauly, best known for his theory of 'fishing down marine food webs' opened the symposium by discussing how commercial fishing may contribute to jellyfish blooms and by encouraging jellyfish researchers to consider using applied fisheries techniques and to communicate better with ecosystem modelers. Professor Bill Hamner and Dr. Mike Dawson presented the plenary talk for the session on Diversity and discussed the phylogeography of jellyfish blooms. Dr. Jenny Purcell led the session on Trophic Ecology and encouraged researchers of jellyfish to start thinking on large, rather than local, 


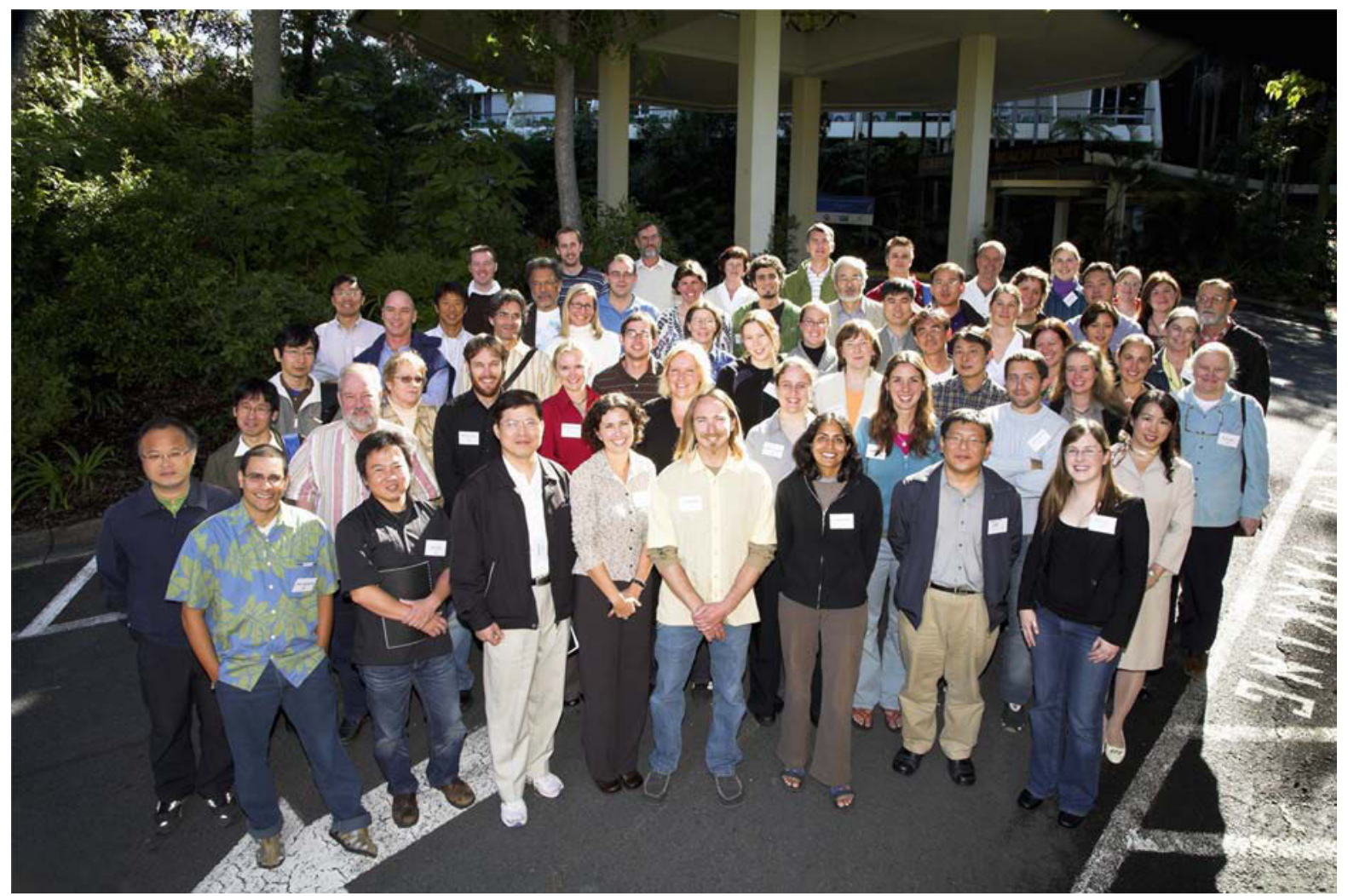

Participants of the Second International Jellyfish Blooms Symposium held at the Gold Coast, Queensland, Australia, 24-27 June 2007

scales. The final session on the Ecology of the Benthic Polyps was led by Professor Gerhard Jarms who emphasized that an understanding of the dynamics of jellyfish blooms required better knowledge of the demographics of the cryptic benthic polyps.

The papers presented in this volume are a subset of the $60+$ talks and posters presented at the meeting. They provide a good representation of the diversity of issues discussed and hopefully will stimulate researchers worldwide to continue research into how and why jellyfish blooms occur.

The guest editors and conference organisers wish to thank the sponsors of the symposium, specifically the Ian Potter Foundation, CSIRO Land and Water, Griffith University, the Australian Rivers Institute (Griffith University), and James Cook University. The guest editors are also indebted to the numerous referees for their detailed and insightful reviews of manuscripts and, of course, to the contributing authors who stoically endured the numerous queries and requests of the guest editors.
Kylie Pitt (conference organiser and guest editor) Jenny Purcell (guest editor)

Jamie Seymour (conference organiser)

\section{Complete list of conference presentations}

Oral presentations

Jellyfish in marine ecosystems. D. Pauly. University of British Columbia, Canada.

The phylogeography of jellyfish blooms. W. M. Hamner ${ }^{1}$, M. N. Dawson ${ }^{2}$. ${ }^{1}$ University of California, Los Angeles, USA; ${ }^{2}$ University of California, Merced, USA.

Phylogeography of an invasive jellyfish indicates multiple independent invasions and intense founder effects. K. M. Bayha ${ }^{1}$, T. Bolton ${ }^{2}$, W. M. Graham ${ }^{1,3} .{ }^{1}$ Dauphin Island Sea Lab, USA; ${ }^{2}$ The Flinders University of South Australia, Australia; ${ }^{3}$ University of South Alabama, USA. 
Molecular analysis of the genus Physalia (Cnidaria: Siphonophora) in New Zealand. D. R. Pontin, R. H. Cruickshank. Lincoln University, New Zealand.

Mitochondrial genomes of two jellyfishes, Aurelia aurita and Chrysaora quinquecirrha. D.-S. Hwang, J.-S. Lee. Hanyang University, South Korea.

Patterns in pelagic cnidarian blooms in the North Atlantic. M. J. Gibbons ${ }^{1}$, A. J. Richardson ${ }^{2}$. ${ }^{1}$ University of the Western Cape, Republic of South Africa; ${ }^{2}$ CSIRO Marine and Atmospheric Research and University of Queensland, Australia.

Population dynamics and dispersal of Pelagia noctiluca in the Adriatic Sea. A. Malej ${ }^{1}$, V. Malačič ${ }^{1}$, A. Malej Jr ${ }^{2}$, M. Malej ${ }^{2}$, A. Ramšak ${ }^{1}$, K. Stopar ${ }^{1}$. ${ }^{1}$ National Institute of Biology;

${ }^{2}$ University of Primorska, Slovenia.

Jellyfish biodiversity in Taiwan, western North Pacific Ocean. W. T. Lo ${ }^{1}$, P. H. Ho ${ }^{2}$. ${ }^{1}$ National Sun Yat-Sen University; ${ }^{2}$ National Taiwan Ocean University, Taiwan, Republic of China.

Jellyfish appearances in Korean waters in 2006. W.

D. Yoon, H. J. Gal, D. Lim, S. J. Chang. National Fisheries Research and Development Institute, Korea.

Ecological niche conservatism in box-jellyfishes. B. Bentlage. University of Kansas, USA.

An overview of the Rhopaliophora (Cnidaria, Medusozoa) research in Indian waters. G. Kan$\operatorname{agaraj}^{1}$, P. Samapthkumar ${ }^{1}$, A. C. Morandini ${ }^{2}$. ${ }^{1}$ Annamalai University, India; ${ }^{2}$ Universidade Federal do Rio de Janeiro, Brazil.

Reconstructing the invasion history of two independent introductions of the ctenophore Mnemiopsis leidyi. K. M. Bayha ${ }^{1}$, G. R. Harbison ${ }^{2}$, J. H. McDonald $^{3}$, P. M. Gaffney ${ }^{4}{ }^{1}$ Dauphin Island Sea Lab, USA; ${ }^{2}$ Woods Hole Oceanographic Institute, USA; ${ }^{3}$ University of Delaware, USA.

Phylogeny of Rhopaliophora and the evolution of the paraphyletic Rhizostomae. I. Straehler-Pohl. University of Hamburg, Germany.

Gelatinous zooplankton trophic ecology in the 21st Century: utilizing broad-scale and predictive approaches. J. E. Purcell. Western Washington University, USA.

Estimation of trophic level of giant jellyfish, Nemopilema nomurai, using stable isotope ratio.
M. Toyokawa. National Institute of Fisheries Research, Japan.

Vertical migration of medusae in the open waters of south Adriatic Sea during $96 \mathrm{~h}$ sampling period (July 2003). D. Lučić ${ }^{1}$, A. Benović ${ }^{1}$, M. Morović $^{2}$, I. Onofri ${ }^{3}$. ${ }^{1}$ University of Dubrovnik, Croatia; ${ }^{2}$ Institute of Oceanography and Fisheries, Croatia; ${ }^{3}$ University of Split, Croatia.

Links between dissolved organic matter excretion by gelatinous zooplankton and bacterial metabolism. R. H. Condon ${ }^{1}$, D. K. Steinberg ${ }^{1}$, T. C. Bouvier ${ }^{2}$, P. A. del Giorgio ${ }^{3}$. ${ }^{1}$ Virginia Institute of Marine Science, USA; ${ }^{2}$ Université de Montpellier, France; ${ }^{3}$ Université du Québec à Montréal, Canada.

The advection of scyphomedusae in the central Baltic Sea-Modelling, field data and possible consequences for trophic interactions. K. Barz ${ }^{1}$, H.-J. Hirche $^{1}$, H.-H. Hinrichson ${ }^{2}$. ${ }^{1}$ Alfred Wegener Institute for Polar and Marine Research, Germany; ${ }^{2}$ Leibniz Institute of Marine Science, Germany.

Ontogeny of association behaviour with jellyfish in jack mackerel Trachurus japonicus revealed by rearing experiment using Aurelia aurita and underwater observation in relation to Nemopilema nomurai. R. Masuda. Kyoto University, Japan.

Bioenergetics in gelatinous zooplankton-the effect of prey species on energetic parameters. L. F. Møller, P. Thor, P. Tiselius. Göteborg University, Sweden.

Development, biological regulation, and fate of Mnemiopsis leidyi blooms in the York River estuary, USA. R. H. Condon, D. K. Steinberg. Virginia Institute of Marine Science, USA.

Jellyfish blooms that coincide with nutrient pulses can generate red tides. K. A. Pitt ${ }^{1}$, M. J. Kingsford ${ }^{2}$, D. Rissik $^{3}$, K. Koop ${ }^{4}$. ${ }^{1}$ Griffith University, Australia; ${ }^{2}$ James Cook University, Australia; ${ }^{3}$ New South Wales Department of Natural Resources, Australia; ${ }^{4}$ New South Wales Department of Environment and Climate Change, Australia.

The polyps of the Scyphozoa and their impact on jellyfish blooms. G. Jarms. University of Hamburg, Germany.

The life-cycle of the deep sea jellyfish Atorella octagonos (Cnidaria: Scyphozoa: Coronatae). A. C. Morandini ${ }^{1}$, S. N. Stampar ${ }^{2}$, H. M. Pacca ${ }^{2}$, 
F. L. da Silveira ${ }^{2}$, G. Jarms ${ }^{3}$. ${ }^{1}$ Universidade Federal do Rio de Janeiro, Brazil; ${ }^{2}$ Universidade de São Paulo, Brazil; ${ }^{3}$ University of Hamburg, Germany.

Morphological plasticity in polyps of Aurelia sp. in response to developmental temperature and food availability, and its subsequent effects on ephyrae: an experimental approach. L. M. Chiaverano ${ }^{1}$, W. M. Graham ${ }^{1,2}$. ${ }^{1}$ University of South Alabama, USA; ${ }^{2}$ Dauphin Island Sea Lab, USA.

Thermal decline and density of population as factors for inducing strobilation and budding in moon jellyfish, Aurelia aurita. N. L. Lim, E. Y. Koh, W. D. Yoon, D. Lim. National Fisheries Research and Development Institute, Korea.

Seasonal changes in the density of Aurelia aurita polyps in the innermost part of Tokyo Bay. H. Ishii, K. Katsukoshi. Tokyo University of Marine Science and Technology, Japan.

Effects of changing environmental conditions on polyp populations and production of ephyrae. S. Holst. University of Hamburg, Germany.

Seasonal lunar spawning periodicity in offshore cubozoans. T. J. Carrette, J. Seymour. James Cook University, Australia.

Visual ecology in two species of box jellyfish. A. Underwood, J. Seymour. James Cook University, Australia.

Movement patterns in the Australian box jellyfish Chironex fleckeri: passive drifters or active locomotors? M. R. Gordon, R. Jones, J. E. Seymour. James Cook University, Australia.

Behavioural responses of zooplankton to the presence of predatory jellyfish. E. F. Carr, K. A. Pitt. Griffith University, Australia.

A comparison of the influence of symbiotic and nonsymbiotic jellyfish on the nutrient cycling of coastal waterways. E. J. West, K. A. Pitt, D. T. Welsh. Griffith University, Australia.

Life cycle of the jellyfish Lychnorhiza lucerna Haeckel, 1880 (Scyphozoa, Rhizostomeae). A. Schiariti $^{1,2}$, M. Kawahara ${ }^{3}$ S. Uye ${ }^{3}$, H. W. Mianzan ${ }^{1,2}$. Instituto Nacional de Investigación y Desarrollo Pesquero, Argentina; ${ }^{2}$ Concejo Nacional de Investigaciones Cientificas y Ténicas, Argentina; ${ }^{3}$ Hiroshima University, Japan.

Real-time field measurements of Aurelia aurita using a Self-Contained Underwater Velocimetry Apparatus
(SCUVA). K. Katija, J. O. Dabiri. California Institute of Technology, USA.

The role of water column structure on jellyfish aggregation and reproduction in shallow coastal waters. W. M. Graham ${ }^{1,2}$, J. E. Higgins III $^{1}$, K. Park ${ }^{1,2}$. ${ }^{1}$ Dauphin Island Sea Lab, USA; ${ }^{2}$ University of South Alabama, USA.

New approach to the understanding of a marine ecosystem using acoustic survey of jellyfish aggregation. G. A. Colombo ${ }^{1}$, A. Benović ${ }^{2}$, M. Acha ${ }^{1}$, D. Lučić ${ }^{2}$, T. Makovec ${ }^{3}$, V. Onofri ${ }^{2}$, A. Malej ${ }^{3}$, H. Mianzan ${ }^{1}$. ${ }^{1}$ Instituto Nacional de Investigación y Desarrollo Pesquero, Argentina; ${ }^{2}$ University of Dubrovnik, Croatia; ${ }^{3}$ National Institute of Biology, Slovenia.

Mechanism and significance of Aurelia aggregations in Uwa Bay, Japan. N. Fujii, Y. Nanjo, J. Ooyama, H. Takeoka. Ehime University, Japan.

Enhancement of jellyfish (Rhopilema esculentum Kishinouye, 1891) in Liaodong Bay, China. J. Dong, L. Jiang, K. Tan, C. Ye, P. Li, B. Wang. Liaoning Ocean and Fisheries Science Research Institute, China.

Recent bloom of the giant jellyfish Nemopilema nomurai in the East Asian Marginal Seas: A brief summary. S. Uye. Hiroshima University, Japan.

Mass appearance of the giant jellyfish, Nemopilema nomurai, along Japanese coasts and countermeasures. H. Iizumi ${ }^{1}$, O. Kato ${ }^{1}$, T. Watanabe ${ }^{2}$. ${ }^{1}$ Japan Sea National Fisheries Research Institute, Fisheries Research Agency, Japan; ${ }^{2}$ National Research Institute of Fisheries Engineering, Japan.

Seasonal change of oocyte size of giant jellyfish, Nemopilema nomurai. M. Toyokawa ${ }^{1}$, A. Shi-

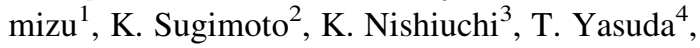
N. Iguchi ${ }^{5}$. ${ }^{1}$ National Research Institute of Fisheries Science, Fisheries Research Agency, Japan; ${ }^{2}$ Fukui Prefectural Fisheries Experimental Station, Japan; ${ }^{3}$ Seikai National Fisheries Research Institute, Fisheries Research Agency, Japan; ${ }^{4}$ Yasuda Fisheries Office, Japan; ${ }^{5}$ Japan Sea National Fisheries Research Institute, Fisheries Research Agency, Japan.

Toxic components in the venom of the Lion's mane jellyfish Cyanea sp. H. Helmholz, C. Ruhnau, S. Lassen, R. Pepelnik, A. Prange. GKSS Research Centre, Germany. 
Poster presentations

Kinematical properties of the jellyfish Aurelia sp. T. Bajcar $^{1}$, V. Malačič ${ }^{2}$, A. Malej ${ }^{2}$, B. Širok ${ }^{1}$. ${ }^{1}$ University of Ljubljana, Slovenia; ${ }^{2}$ National Institute of Biology, Slovenia.

Prospects of molecular systematics for Cubozoa. B. Bentlage $^{1}$, A. G. Collins ${ }^{2}$, P. Cartwright ${ }^{1}$. ${ }^{1}$ Uni- $^{-}$ versity of Kansas, USA; ${ }^{2}$ NOAA's National Systematics Lab and National Museum for Natural History, Washington, DC, USA.

Nematocysts and morphometrics of lion's mane jellyfishes, genus Cyanea, supporting the validity of C. nozakii and C. annaskala in Australian waters. R. H. Condon ${ }^{1}$, M. D. Norman ${ }^{2}$, K. M. Bayha ${ }^{3}$. ${ }^{1}$ Virginia Institute of Marine Science, USA; ${ }^{2}$ Museum of Victoria, Australia; ${ }^{3}$ Dauphin Island Sea Lab, USA.

Life cycle of a sea anemone parasite on Aurelia sp. from Veliko Jezero (Mljet, Croatia). I. D'Ambra, W. M. Graham. Dauphin Island Sea Lab and University of South Alabama, USA.

Preliminary observations on the diet and feeding of Chrysaora hysoscella from Walvis Bay Lagoon, Namibia. B. Flynn, M. J. Gibbons. University of the Western Cape, Republic of South Africa.

Seasonal variations in abundance, biomass and trophic role of Aurelia aurita s.l. medusae in a brackish water lake, Japan. C. H. Han, M. Kawahara, S. Uye. Hiroshima University, Japan.

Complete mitochondrial genomes of two jellyfish, Aurelia sp. 1 (like A. aurita) and Dactylometra quinquecirrha. D.-S. Hwang ${ }^{1}$, J.-S. Ki ${ }^{1}$, Y. S. $\mathrm{Kang}^{2}$, K. Shin ${ }^{3}$, J.-S. Lee ${ }^{1}$. ${ }^{1}$ Hanyang University, South Korea; ${ }^{2}$ National Fisheries Research and Development Institute, South Korea; ${ }^{3}$ Korea Ocean Research and Development Institute, South Korea.

Biological characteristics of benthic polyp and planktonic juvenile stages of the giant jellyfish Nemopilema nomurai. M. Kawahara, S. Uye. Hiroshima University, Japan.

Importance of jellyfish molecular analysis for global expansion and a parallel high throughput DNAchip detection. J.-S. Ki, D.-S. Hwang, J.-S. Lee. Hanyang University, South Korea.

Population studies of Aurelia aurita from Southampton Water and Horsea Lake, UK. C. H.
Lucas. National Oceanography Centre Southampton, University of Southampton, U.K.

Characterization of microsatellite markers for three species of invasive hydrozoans in the San Francisco Estuary, CA, USA. M. H. Meek, M. R. Baerwald, B. P. May. University of California, Davis, USA.

The influence of ecological and physical factors on the settlement and viability of the moon jelly (Scyphozoa; Aurelia sp.) in the Northern Gulf of Mexico. M.-E. C. Miller, W. M. Graham. Dauphin Island Sea Lab and University of South Alabama, USA.

Population structure of the scyphomedusae Chrysaora lactea and Lychnorhiza lucerna (Cnidaria: Scyphozoa: Discomedusae) in an estuarine area on southeastern Brazil. A. C. Morandini ${ }^{1}$, S. N. Stampar $^{2}$, F. L. da Silveira ${ }^{2}{ }^{1}$ Universidade Federal do Rio de Janeiro, Brazil; ${ }^{2}$ Universidade de São Paulo, Brazil.

Scolionema or Gonionemus (Cnidaria: Hydrozoa: Limnomedusae): morphology and life cycle helping to solve taxonomical problems. A. C. Morandini $^{1}$, S. N. Stampar ${ }^{2}$, V. B. Tronolone ${ }^{2}$. ${ }^{1}$ Universidade Federal do Rio de Janeiro, Brazil; ${ }^{2}$ Universidade de São Paulo, Brazil.

Stable isotopes emphasise the importance of large and emergent zooplankton to the diet of jellyfish. K. A. Pitt $^{1}$, A.-L. Clement ${ }^{1,2}$, R. M. Connolly ${ }^{1}$, D. Thibault-Botha ${ }^{2}$. ${ }^{1}$ Griffith University, Australia; ${ }^{2}$ Aix-Marseille Université, France.

Recruitment to benthic phase of planula and growth of scyphozoan polyps (Aurelia aurita). K. Shin, W. J. Lee, D. H. Son. Korea Ocean Research and Development Institute, Korea.

Effects of warming and low dissolved oxygen upon survival and asexual reproduction of scyphozoan polyps (Aurelia aurita s.l.). M. Takao, S. Uye. Hiroshima University, Japan.

Interactions between fishes and invasive jellyfish in the upper San Francisco Estuary, USA. A. P. Wintzer, P. B. Moyle. University of California, Davis, USA.

A new enzyme-assay for PLA2 activity in jellyfish venom based on phosphorus detection using HPLC-CC-ICP-MS. A. Zimmermann ${ }^{1,2}, \mathrm{H}$. Helmholz $^{1}$, D. Pröfrock ${ }^{1}$, A. Prange ${ }^{1}$. ${ }^{1}$ GKSS Research Centre, Germany; ${ }^{2}$ University of Hamburg, Germany. 